\title{
Not GABA But Glycine Mediates Segmental, Propriospinal, and Bulbospinal Postsynaptic Inhibition in Adult Mouse Spinal Forelimb Motor Neurons
}

\author{
- Tuan Jiang and Bror Alstermark \\ Department of Integrative Medical Biology, Section of Physiology, Umeå University, S-901 87 Umeå, Sweden
}

\begin{abstract}
The general view is that both glycine (Eccles, 1964) and GABA (Curtis and Felix, 1971) evoke postsynaptic inhibition in spinal motor neurons. In newborn or juvenile animals, there are conflicting results showing postsynaptic inhibition in motor neurons by corelease of GABA and glycine (Jonas et al., 1998) or by glycine alone (Bhumbra et al., 2012). To resolve the relative contributions of GABA and glycine to postsynaptic inhibition, we performed in vivo intracellular recordings from forelimb motor neurons in adult mice. Postsynaptic potentials evoked from segmental, propriospinal, and bulbospinal systems in motor neurons were compared across four different conditions: control, after gabazine, gabazine followed by strychnine, and strychnine alone. No significant differences were observed in the proportion of IPSPs and EPSPs between control and gabazine conditions. In contrast, EPSPs but not IPSPs were recorded after adding strychnine with gabazine or administering strychnine alone, suggesting an exclusive role for glycine in postsynaptic inhibition. To test whether the injected (intraperitoneal) dose of gabazine blocked GABAergic inhibitory transmission, we evoked $\mathrm{GABA}_{\mathrm{A}}$ receptormediated monosynaptic IPSPs in deep cerebellar nuclei neurons by stimulation of Purkinje cell fibers. No monosynaptic IPSPs could be recorded in the presence of gabazine, showing the efficacy of gabazine treatment. Our results demonstrate that, in the intact adult mouse, the postsynaptic inhibitory effects in spinal motor neurons exerted by three different systems, intrasegmental and intersegmental as well as supraspinal, are exclusively glycinergic. These findings emphasize the importance of glycinergic postsynaptic inhibition in motor neurons and challenge the view that GABA also contributes.
\end{abstract}

Key words: adult; GABA; glycine; inhibition; motor neuron; mouse

\section{Introduction}

In the early 1960s, it was believed that postsynaptic inhibition in motor neurons was evoked by glycine (Eccles, 1964), but later the view changed, and it is now generally agreed that GABA also mediates postsynaptic inhibition (Curtis and Felix, 1971), in addition to its well characterized role in evoking presynaptic inhibition in the spinal cord (Rudomin and Schmidt, 1999; Fink et al., 2014). The abundance of GABAergic and glycinergic synaptic terminals, some of which coexist in the same terminals, and the presence of their respective postsynaptic receptors on motor neurons is well documented by morphological evidence (Holstege and Calkoen, 1990; Ornung et al., 1996; Todd et al., 1996; Frazao et al., 2007). Moreover, ex vivo electrophysiological studies in neonatal rat suggest that glycine and GABA can be coreleased in spinal motor neurons [postnatal day 5 (P5) to P10; Jonas et al.,

Received April 22, 2014; revised Dec. 12, 2014; accepted Dec. 16, 2014.

Author contributions: J.J. and B.A. designed research; J.J. and B.A. performed research; J.J. and B.A. analyzed data; J.J. and B.A. wrote the paper.

This work was supported by grants from the Swedish Research Council (B.A.). J.J. was supported by grants to B.A. from Umeå University. We thank T. Isa and E. Azim for valuable comments on a previous version of this manuscript and E. Danielsson and P. Utsi for skilled technical support.

The authors declare no competing financial interests.

Correspondence should be address to Bror Alstermark, Department of Integrative Medical Biology, Section of Physiology, Umeå University, S-901 87 Umeå, Sweden. E-mail: bror.alstermark@umu.se.

DOI:10.1523/JNEUROSCI.1627-14.2015

Copyright $\odot 2015$ the authors $\quad 0270-6474 / 15 / 351991-08 \$ 15.00 / 0$
1998] or brain stem hypoglossal neurons (P1-P5) and abducens motor neurons (P5-P13; O'Brien and Berger, 1999; Russier et al., 2002). In contrast, GABA is not coreleased at glycinergic synapses in lumbar motor neurons in P8-P14 mice (Bhumbra et al., 2012). In addition, the inhibitory effects mediated by glycine quickly increase whereas those of GABA decrease during early postnatal development (Gao et al., 2001; Nabekura et al., 2004; Muller et al., 2006). Thus, the relative contribution of glycinergic and GABAergic postsynaptic inhibition in adult motor neurons remains unclear. Furthermore, many of the classical electrophysiological studies were performed in cats (Eccles, 1964; Curtis and Felix, 1971), whereas rodents are an increasingly used animal model for spinal physiology. Therefore, investigation of this issue in mice can help resolve the nature of spinal postsynaptic inhibition and identify or exclude potential species differences.

In this study, we investigated the effect of GABA and glycine in postsynaptic inhibition by in vivo intracellular recordings in forelimb motor neurons evoked from three different systems in adult mice. The first is the segmental interneuronal system, which can be recruited by activation of muscle primary spindle Ia afferents, which in turn engage monosynaptic excitation in agonist motor neurons and reciprocal Ia inhibition in antagonistic motor neurons (Baldissera et al., 1981). The second is the C3-C4 propriospinal system; propriospinal neurons (PNs) have dual projections to forelimb motor neurons and neurons in the lateral reticular nucleus 
(LRN). Previous studies in the cat, monkey, and mouse have shown that electrical stimulation of the ascending branch of the PNs in the LRN antidromically activates PNs and evokes both excitation and inhibition in forelimb motor neurons (Illert and Tanaka, 1978; Alstermark et al., 1984; Isa et al., 2006; Azim et al., 2014). The third is the bulbospinal pathway, which can be recruited by electrical stimulation in the medial longitudinal fascicle (MLF), eliciting both excitation and inhibition in mouse forelimb motor neurons (Alstermark and Ogawa, 2004). Combining these stimulation approaches with pharmacology, we explored the relative contributions of glycine and GABA to the postsynaptic inhibition of forelimb motor neurons.

\section{Materials and Methods}

Preparation. The experiments were performed on 28 anesthetized mice (15 males and 13 females; age, 2-14 months) with body weights of $28.48 \pm 3.94$ g. All experimental procedures were approved by the Umeå University Ethics Committee and followed National Institutes of Health and European Union guidelines for animal care.

Anesthesia was induced with a 1:1 mixture of Hypnorm $(0.08 \mathrm{mg} / \mathrm{ml}$ fentanyl citrate and $2.5 \mathrm{mg} / \mathrm{ml}$ fluanisone; VetaPharma) and Dormicum $(1.25 \mathrm{mg} / \mathrm{ml}$ midazolam; Roche) at an initial dose of $0.15 \mathrm{ml}$ supplemented with doses of $0.02 \mathrm{ml}$ via intraperitoneal (i.p.) injection. Atropin $(0.1 \mathrm{mg} / \mathrm{ml}, 0.1 \mathrm{ml}$; Mylan $)$ and Betapred $(0.8 \mathrm{mg} / \mathrm{ml}, 0.1 \mathrm{ml}$; Unipessoal $)$ were always given via intramuscular injection just before tracheotomy. Pavulon $(20 \mu \mathrm{g} / \mathrm{ml}, 0.1 \mathrm{ml}$; Organon) was given after tracheotomy and readministered approximately every $30 \mathrm{~min}$. Hypnorm $(31.5 \mu \mathrm{g} / \mathrm{ml}$ fentanyl citrate and $1.0 \mathrm{mg} / \mathrm{ml}$ fluanisone; $0.1 \mathrm{ml}$; VetaPharma) was given if the heart rate increased to $600 \mathrm{bpm}$. Ephedrine $(10 \mathrm{mg} / \mathrm{ml}, 0.1 \mathrm{ml}$; NM Pharma) was given if $\mathrm{pCO}_{2}$ decreased below $3.0 \%$ for $>5 \mathrm{~min}$.

Tracheotomy, pneumothorax, and artificial respiration (rate, 60/min; volume, $50 \mathrm{ml}$ flow air plus $\mathrm{O}_{2}$ ) were always performed. Body temperature was maintained at $36-38^{\circ} \mathrm{C}$, and the heart rate $(400-500$ beats/min) and expiratory $\mathrm{CO}_{2}$ were monitored continuously and kept within the physiological range using a $\mathrm{pCO}_{2}$ meter (Datex type CD-200-23-00; Instrumentarium). The animal was mounted in a head holder built by Lennart Näslund (Umeå University) for stereotaxic placement of brain electrodes.

A laminectomy was performed to expose the spinal cord for recording from the sixth to the seventh cervical segments (C6-C7). A craniotomy exposed the caudal part of the cerebellum and brainstem for stimulation. The deep radial (DR) nerve was stimulated with bipolar needle electrodes inserted into the upper forelimb muscles. DR stimulation was also used for guidance to antidromically identify the lateral motor nuclei. Cord dorsum potentials were recorded with a silver ball electrode on the surface of the spinal cord near the recording site to monitor the incoming volley.

Stimulation and recording. The ipsilateral DR nerve was stimulated with constant voltage $[0.1 \mathrm{~ms}$ duration, intensity expressed in the multiples of threshold ( $\mathrm{T}$ ) for the lowest threshold fibers in the nerve]. The ascending branch of the PNs was stimulated with a tungsten electrode ( $100 \mathrm{~K} \Omega$ impedance) inserted into the LRN at $1.3 \mathrm{~mm}$ caudal to obex, 1.3 $\mathrm{mm}$ ipsilateral from the midline, and $1.0-1.2 \mathrm{~mm}$ ventral from the brainstem surface. The bulbospinal tract fibers were stimulated in the contralateral MLF at $1.0 \mathrm{~mm}$ rostral to obex, $0.3 \mathrm{~mm}$ contralateral from the midline, and $0.5-1.0 \mathrm{~mm}$ ventral from the surface of the brainstem. A train of one to four stimuli was given at $300 \mathrm{~Hz}, 100 \mu \mathrm{A}$. Recording of the descending volley was performed from the surface of the lateral funiculus in the middle part of the $\mathrm{C} 6-\mathrm{C} 7$ segments using a silver ball electrode. When recording from deep cerebellar nucleus (DCN) neurons, the Purkinje cell fibers were stimulated at $2.5-3.0 \mathrm{~mm}$ rostral to obex, $1.0 \mathrm{~mm}$ ipsilateral from the midline, and $1.0-1.5 \mathrm{~mm}$ ventral from the surface of cerebellum $(100 \mu \mathrm{A})$.

Intracellular motor neuron recordings were conducted by using sharp borosilicate glass micropipettes (10-20 M $\Omega$ impedance) filled with $2 \mathrm{M}$ potassium citrate, $\mathrm{pH}$ 7.4. The DR motor neurons were identified by antidromic activation after DR stimulation at $5 \times \mathrm{T}$. We also included unidentified motor neurons recorded in the same tracks as DR motor neuron recordings. Intracellularly recorded postsynaptic potentials were compared by recording the extracellular field potentials just outside the cell. Subtraction between the intracellular and extracellular recordings revealed excitatory, inhibitory, or mixed postsynaptic potentials. DCN neurons were recorded intracellularly from different positions: $2.0-2.5$ $\mathrm{mm}$ rostral to obex, $1.5-2.5 \mathrm{~mm}$ ipsilateral from the midline, and $1.0-2.0$ $\mathrm{mm}$ ventral from the surface of the cerebellum, with a $6^{\circ}$ medial to $2^{\circ}$ lateral angle.

Data acquisition and analysis. Data were acquired using pClamp software and analyzed off-line using Clampfit (Molecular Devices). Because of mechanical instability caused by respiratory and circulatory movements in the cervical spinal cord, it was usually not possible to maintain stable intracellular recordings in vivo for longer than 5 min (usually between 2 and $3 \mathrm{~min}$ ). Postsynaptic potentials were recorded from each motor neuron in one of four conditions: control, after $20 \mathrm{~min}$ of gabazine ( $10 \mu \mathrm{g} / \mathrm{ml}$, i.p.; initial dose, $0.4 \mathrm{ml}$; supplemented with doses of $0.2 \mathrm{ml}$; maximal dose, $1.0 \mathrm{ml}$; Sigma-Aldrich), after $20 \mathrm{~min}$ of strychnine (1 $\mathrm{mg} / \mathrm{ml}$, i.p.; initial dose, $0.1 \mathrm{ml}$; supplemented with doses of $0.1 \mathrm{ml}$; maximal dose, $0.3 \mathrm{ml}$; Sigma-Aldrich), or in the presence of both gabazine and strychnine. The gabazine, strychnine, and strychnine after gabazine groups refer to the motor neurons recorded in adult mice treated with gabazine, strychnine alone, or gabazine followed by strychnine, respectively. All experiments began by recording motor neurons in the untreated control condition. The proportion of cells with excitatory or inhibitory effects was compared for each of the conditions above. The peak amplitude of EPSPs was measured in cells with membrane potentials less than $-30 \mathrm{mV}$, whereas the peak amplitude of IPSPs was measured in cells that showed only IPSPs and not mixed EPSPs and IPSPs. Data are presented as percentage or mean \pm SD and were analyzed with Statistica (StatSoft). Statistical tests consisted of the unpaired Student's $t$ test or $\chi^{2}$ test, and differences were considered to be significant at $p<$ 0.05. After each experiment, the stimulation and recording sites were verified histologically.

\section{Results}

A critical point in this in vivo study is whether the $\mathrm{GABA}_{\mathrm{A}}$ receptor antagonist gabazine, administered by intraperitoneal injection, reached effective concentrations to block GABAergic transmission. Therefore, we performed control experiments by recording from $\mathrm{DCN}$ neurons while evoking $\mathrm{GABA}_{\mathrm{A}}$ receptormediated monosynaptic IPSPs via stimulation of Purkinje cell fibers (Fig. 1E). All DCN cells receive GABAergic monosynaptic inhibition from Purkinje cells (Ito et al., 1970), indicating the suitability of this system. Monosynaptic IPSPs could be evoked in all of the recorded DCN neurons $(n=10)$ before gabazine injection (one example illustrated in Fig. $1 A$ ). As shown in Figure $1 B$ for another DCN cell, we observed no IPSPs after gabazine injection $(0.4-1.0 \mathrm{ml}, 10 \mu \mathrm{g} / \mathrm{ml}$, i.p.) in any of the recorded cells $(n=$ 23 ). These results demonstrate that the concentration of gabazine was sufficient to fully block $\mathrm{GABA}_{\mathrm{A}}$ receptors. In contrast, as shown in Figure $1 C$, large monosynaptic IPSPs could still be evoked by stimulation of the Purkinje cell fibers $(n=11)$ after injection of the glycine receptor antagonist strychnine $(0.1-0.3 \mathrm{ml}, 1$ $\mathrm{mg} / \mathrm{ml}$, i.p.), confirming the GABAergic source of this inhibition. Figure $1 D$ shows histology confirmed recording in the DCN neurons.

To explore the relative contributions of GABA and glycine to postsynaptic inhibition in spinal motor neurons, we recorded intracellularly from 156 motor neurons identified antidromically by DR stimulation and 61 unidentified motor neurons in adult mice. We evoked postsynaptic inhibition from three different premotor systems under four different conditions: control, gabazine injection, strychnine after gabazine injection, and strychnine injection. Recordings were made at a membrane potential of approximately $-30 \mathrm{mV}$, which favors the size of the IPSPs mediated by $\mathrm{Cl}^{-}$that has a reversal potential of approximately $-70 \mathrm{mV}$ 
A

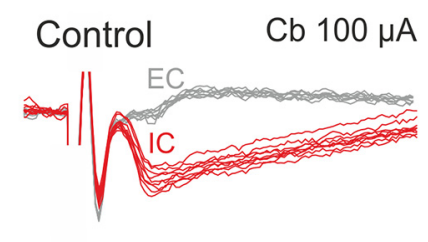

B

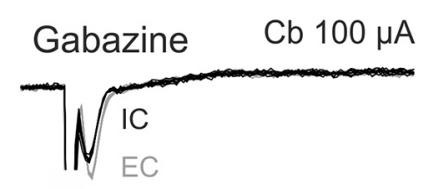

C

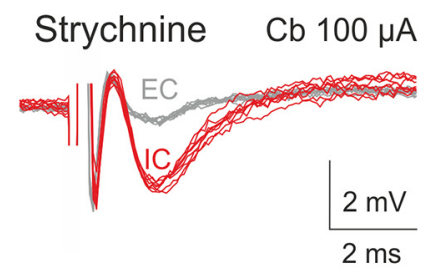

D

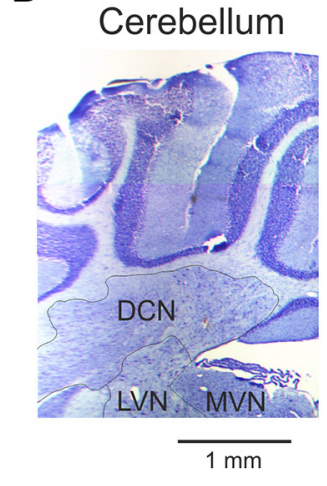

E

Stim Purkinje fibers in the Cerebellum

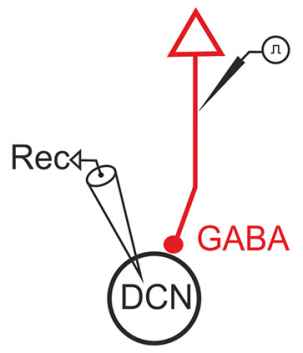

Figure 1. Gabazine, but not strychnine, completely blocks monosynaptic IPSPs in DCN neurons evoked by stimulation of Purkinje cell fibers. $A$, Control, electrical stimulation in the cerebellar white matter (Purkinje fibers) evoked monosynaptic IPSPs (red) in DCN neurons $(n=10)$. $\boldsymbol{B}$, No monosynaptic IPSPs after gabazine injection (black; $n=23$ ). C, Monosynaptic IPSPs after strychnine injection (red; $n=11$ ). Gray lines show extracellular fields. $\boldsymbol{D}$, Histology confirmed recording in the DCN. DCN, deep cerebellar nuclei; LVN, lateral vestibular nucleus; MVN, medial vestibular nucleus. $\boldsymbol{E}$, Schematic drawing of pathway. Cb, cerebellar white matter; IC, intracellular recordings; $\mathrm{EC}$, extracellular recordings.

(Coombs et al., 1955; Curtis et al., 1968). No significant differences in membrane potentials were found among the control, gabazine, strychnine after gabazine, and strychnine groups (Table 1).

\section{Postsynaptic inhibition in motor neurons evoked by segmental interneurons}

To explore the inhibitory effects of segmental interneurons, we examined postsynaptic potentials (PSPs) evoked from muscle afferent fibers to forelimb motor neurons by stimulating the ipsilateral DR (Fig. 2I). Of the 46 recorded motor neurons (control group), $34.78 \%$ (16 of 46) showed EPSPs, 26.09\% (12 of 46) showed IPSPs, and $39.13 \%$ (18 of 46) showed mixed PSPs (both EPSPs and IPSPs) (Fig. 2A). The latencies measured from the incoming volley recorded in the same segments as the motor neurons showed monosynaptic EPSPs (latency, $<1 \mathrm{~ms}$ ) and disynaptic or poly-synaptic IPSPs (Fig. 2D). The mean latencies of EPSPs, IPSPs, EPSPs of mixed PSPs, and IPSPs of mixed PSPs are shown in Table 2 . Figure $2 H$ shows an antidromic spike in a DR motor neuron.

To investigate the effect of fast GABAergic transmission in the segmental interneuronal system, we blocked $\mathrm{GABA}_{\mathrm{A}}$ receptors by gabazine administration $(0.4-1.0 \mathrm{ml}, 10 \mu \mathrm{g} / \mathrm{ml}$, i.p.). Figure $2 B$ shows EPSPs, IPSPs, and mixed PSPs after gabazine injection. In the presence of gabazine, we still observed an incidence of $35.42 \%$ (17 of 48) EPSPs, $29.17 \%$ (14 of 48) IPSPs, and 35.42\% (17 of 48) mixed PSPs in 48 forelimb motor neurons (gabazine group; Fig.

$2 G$ ). The latencies of EPSPs were in a monosynaptic range and IPSPs in a di-synaptic or poly-synaptic range (Fig. 2E, Table 2). There were no statistically significant differences in the proportion of EPSPs and IPSPs compared with the untreated control condition ( $\chi^{2}$ test, $p=0.92$; Fig. $2 G$ ). Moreover, no significant differences were observed in the peak amplitude of monosynaptic EPSPs and di-synaptic or poly-synaptic IPSPs between the control and gabazine groups (Table 3 ). Thus, these data suggest that GABAergic postsynaptic inhibition from segmental interneurons has no significant effect in transmission from forelimb afferents to motor neurons.

We next explored the contribution of glycine receptors to afferent-evoked IPSPs by using the glycine receptor antagonist strychnine (Curtis et al., 1967). In 29 recorded motor neurons (strychnine after gabazine group), all IPSPs disappeared, and only EPSPs could be recorded in the presence of gabazine followed by strychnine $(0.1-0.3 \mathrm{ml}, 1 \mathrm{mg} / \mathrm{ml}$, i.p.). Furthermore, only EPSPs could be observed after strychnine injection alone in the 30 motor neurons examined (strychnine group; Fig. 2C). The mean latencies of EPSPs were in a monosynaptic and di-synaptic or poly-synaptic range (Fig. 2F, Table 2). Across motor neurons, we found a striking difference in the proportion of EPSPs and IPSPs between the control and strychnine after gabazine groups; between the control and strychnine groups; between the gabazine and strychnine after gabazine groups; and between the gabazine and strychnine groups ( $\chi^{2}$ test, $p<0.0001$ in all four comparisons; Fig. $2 G)$. Therefore, these data show that the inhibitory effects in forelimb motor neurons exerted by segmental interneurons are exclusively glycinergic.

\section{Postsynaptic inhibition in motor neurons evoked from the propriospinal system}

We tested the contributions of glycine and $\mathrm{GABA}_{\mathrm{A}}$ receptors to postsynaptic inhibitory transmission evoked from PNs by stimulating the ascending PN axonal branch in the ipsilateral LRN. We recorded $25.00 \%$ ( 9 of 36) EPSPs, $13.89 \%$ ( 5 of 36 ) IPSPs, and $61.11 \%$ (22 of 36) mixed PSPs in the control group ( $n=36$ motor neurons). In the gabazine group ( $n=29$ motor neurons), we found similar results: $20.69 \%$ (6 of 29) EPSPs, 34.48\% (10 of 29) IPSPs, and $44.83 \%$ (13 of 29 ) mixed PSPs. There was no significant difference in the proportion of EPSPs and IPSPs between the control and gabazine groups ( $\chi^{2}$ test, $p=0.14$; Fig. $\left.3 G\right)$. Moreover, we found no significant differences in the peak amplitudes of EPSPs and IPSPs between the control and gabazine groups (Table 3 ). In contrast, strychnine completely blocked all IPSPs $\left(\chi^{2}\right.$ test, $\left.p<0.0001\right)$, leaving only EPSPs in the strychnine group and the strychnine after gabazine group. Figure 3 shows sample recordings (Fig. $3 A-C$ ), latencies (Fig. $3 D-F$ ), and the proportion of EPSPs and IPSPs (Fig. $3 G$ ) in each group, as well as the experimental designs (Fig. $3 H$ ). The mean latencies of EPSPs were in a monosynaptic range and IPSPs in a di-synaptic or poly-synaptic range (Table 2). Therefore, these data suggest that postsynaptic inhibitory transmission from PNs to forelimb motor neurons is also mediated exclusively by glycine receptors.

\section{Postsynaptic inhibition in motor neurons evoked from the bulbospinal system}

We investigated the roles of glycine and $\mathrm{GABA}_{\mathrm{A}}$ receptors in postsynaptic inhibitory transmission evoked from bulbospinal pathways by stimulating the contralateral MLF. Figure 4 shows sample recordings (Fig. $4 A-C$ ), latencies (Fig. $4 D-F$ ), the proportion of EPSPs and IPSPs (Fig. $4 G$ ) in each group, and the 
Table 1. Membrane potentials (mean $\pm \mathrm{SD}, \mathrm{mV}$ ) of motor neurons in four groups

\begin{tabular}{lllll}
\hline & Control & Gabazine & Strychnine after gabazine & Strychnine \\
\hline DR stimulation & $-29.98 \pm 9.35(n=46)$ & $-31.85 \pm 12.50(n=48)$ & $-31.93 \pm 12.03(n=29)$ & $-31.10 \pm 15.17(n=30)$ \\
LRN stimulation & $-32.22 \pm 11.99(n=36)$ & $-31.24 \pm 13.46(n=29)$ & $-33.86 \pm 12.40(n=22)$ & $-29.38 \pm 10.67(n=29)$ \\
MLF stimulation & $-30.24 \pm 13.64(n=70)$ & $-30.27 \pm 12.14(n=51)$ & $-30.18 \pm 10.43(n=34)$ & $-29.27 \pm 13.00(n=49)$ \\
\hline
\end{tabular}

A

Control

DR 5×T
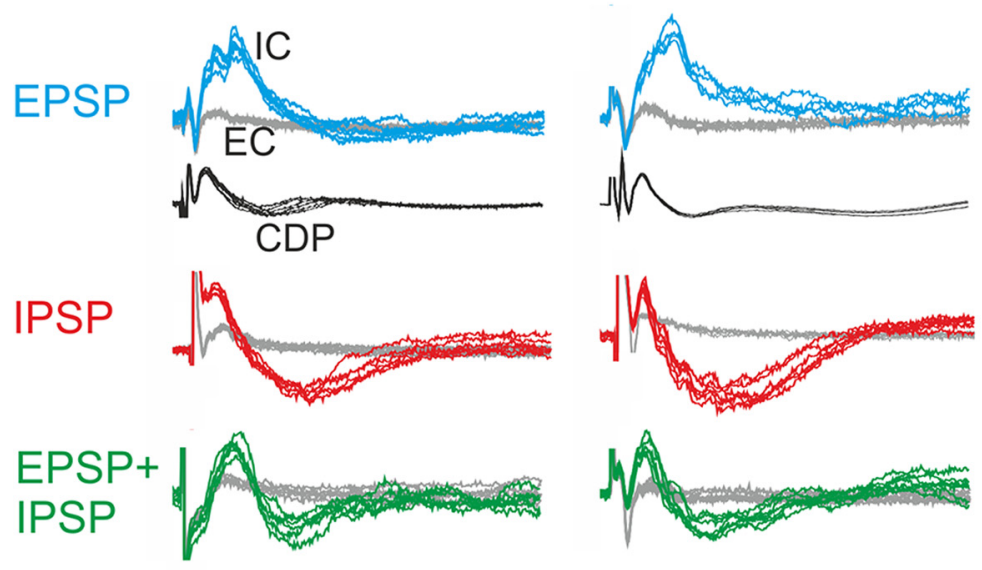

D

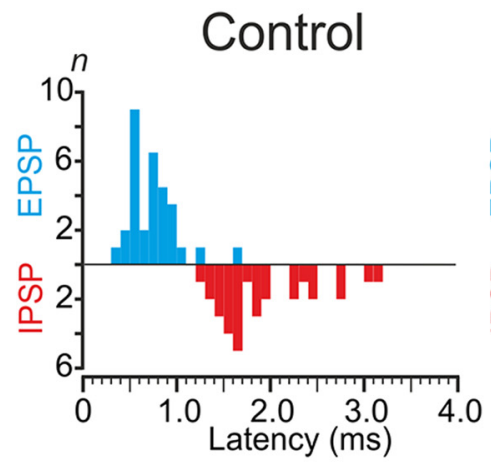

G

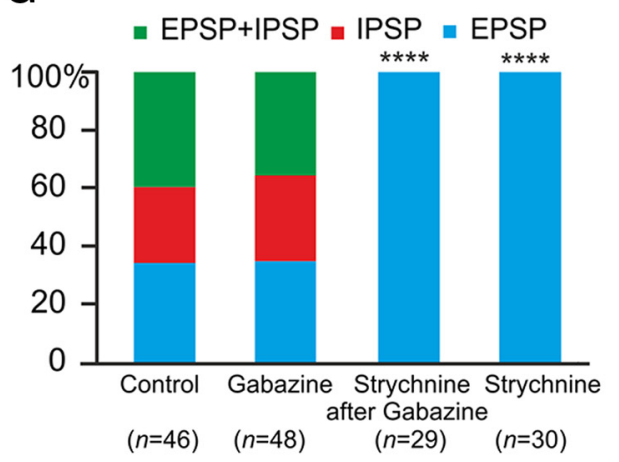

H

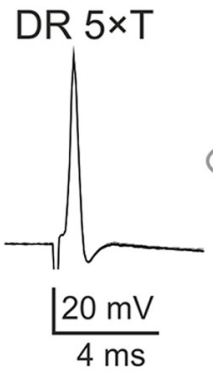

C

\section{Strychnine}

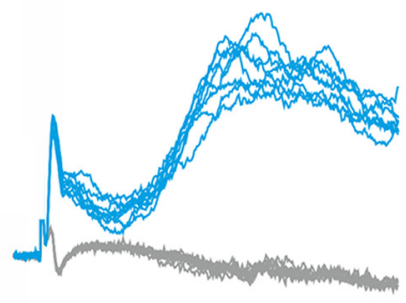

th

\section{$\frac{2 \mathrm{mV}}{5 \mathrm{~ms}}$}

E

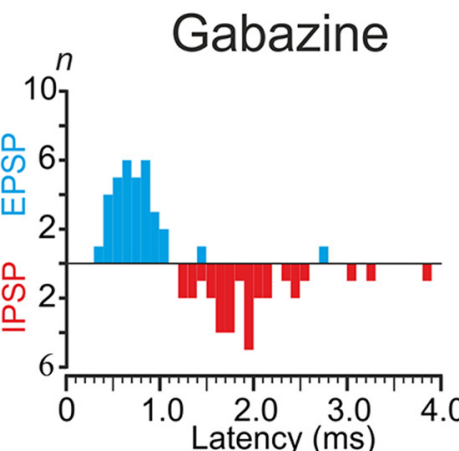

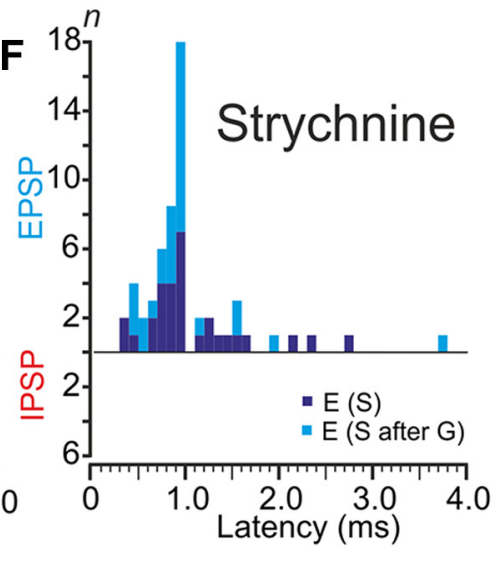

Figure 2. Effects of gabazine and strychnine on postsynaptic potentials evoked in (6-C7 motor neurons by stimulation of the ipsilateral DR nerve. $\boldsymbol{A}$-C, Samples of EPSPs (blue), IPSPs (red), and mixed PSPs (green) evoked from DR motor neurons in the control $(\boldsymbol{A})$, gabazine $(\boldsymbol{B})$, and strychnine after gabazine $(\boldsymbol{C})$ groups. Black lines show the cord dorsum potential (CDP) recorded at the same segment as the motor neuron. IC, Intracellular recordings; EC, extracellular recordings (gray lines). D-F, Segmental latencies of EPSPs and IPSPs in each group. G, Comparison of proportions of EPSPs (blue), IPSPs (red) and EPSP + IPSPs (green) after gabazine or strychnine injection. ${ }^{* * * *} p<0.0001, \chi^{2}$ test, strychnine or strychnine after gabazine injections versus control, respectively. $\boldsymbol{H}$, Antidromic spike from a DR motor neuron. I, Experimental design. IN, interneurons; MN, motor neurons. 
Table 2. Latencies (mean \pm SD, $\mathrm{ms}$ ) and numbers of EPSPs and IPSPs in four groups

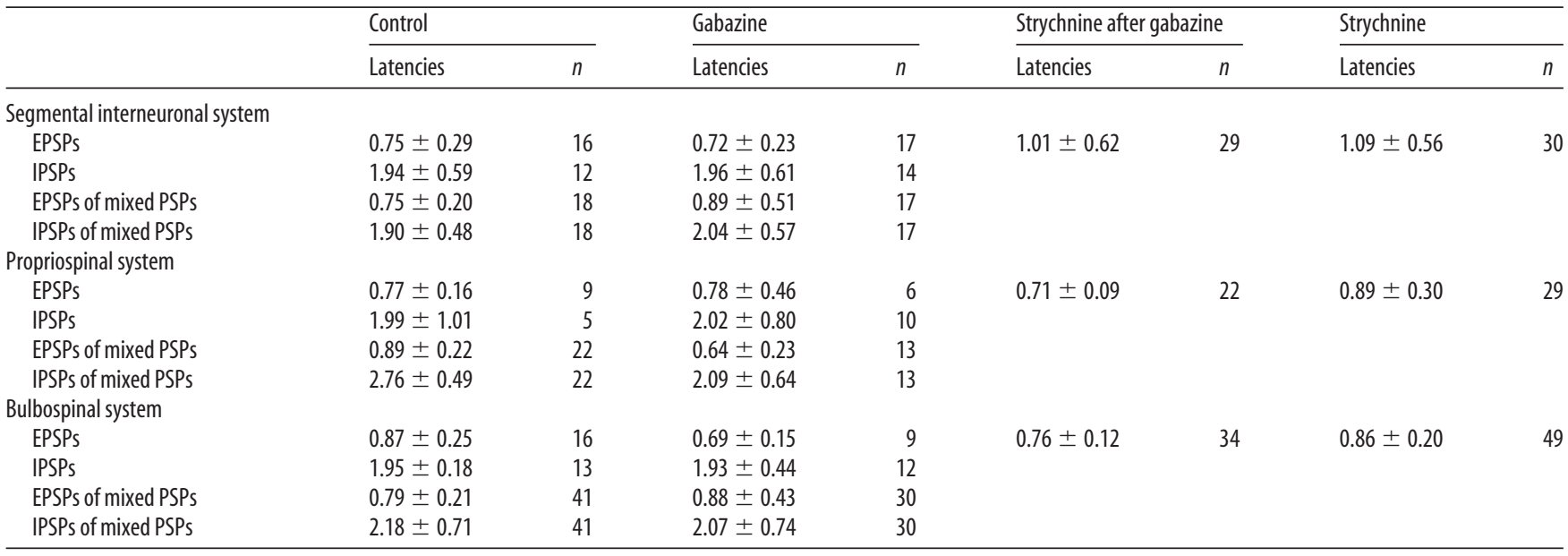

Table 3. Peak amplitude and membrane potentials of EPSPs and IPSPs (mean \pm SD, ms) between the control and gabazine groups

\begin{tabular}{|c|c|c|c|c|c|c|}
\hline & \multicolumn{3}{|l|}{ Control } & \multicolumn{3}{|l|}{ Gabazine } \\
\hline & Peak amplitude & Membrane potentials & $n$ & Peak amplitude & Membrane potentials & $n$ \\
\hline \multicolumn{7}{|c|}{ Segmental interneuronal system } \\
\hline EPSPS & $1.55 \pm 0.94$ & $-35.00 \pm 6.07$ & 16 & $1.73 \pm 0.75$ & $-42.31 \pm 8.25$ & 16 \\
\hline IPSPS & $1.19 \pm 0.78$ & $-28.33 \pm 8.74$ & 12 & $1.72 \pm 1.34$ & $-29.64 \pm 7.46$ & 14 \\
\hline \multicolumn{7}{|c|}{ Propriospinal system } \\
\hline EPSPS & $2.29 \pm 1.46$ & $-42.08 \pm 11.38$ & 14 & $3.41 \pm 1.89$ & $-41.43 \pm 9.13$ & 13 \\
\hline IPSPS & $1.17 \pm 0.65$ & $-29.80 \pm 7.01$ & 15 & $1.59 \pm 1.51$ & $-21.90 \pm 8.58$ & 10 \\
\hline \multicolumn{7}{|c|}{ Bulbospinal system } \\
\hline EPSPS & $1.25 \pm 0.80$ & $-40.52 \pm 8.73$ & 27 & $1.34 \pm 1.05$ & $-40.64 \pm 8.82$ & 22 \\
\hline IPSPs & $1.56 \pm 0.75$ & $-26.69 \pm 15.78$ & 13 & $1.76 \pm 0.88$ & $-23.00 \pm 11.79$ & 12 \\
\hline
\end{tabular}

experimental designs (Fig. 4H). The mean latencies of EPSPs were in a monosynaptic range and IPSPs in a di-synaptic or polysynaptic range (Table 2). The proportion of EPSPs, IPSPs, and mixed PSPs were $22.86 \%$ ( 16 of 70 ), $18.57 \%$ (13 of 70 ), and $58.57 \%$ ( 41 of 70$)$ in the control group ( $n=70$ motor neurons) and $17.65 \%$ ( 9 of 51 ), $23.53 \%$ (12 of 51 ), and $58.82 \%$ (30 of 51 ) in the gabazine group ( $n=51$ motor neurons). No significant differences in the peak amplitudes of EPSPs and IPSPs were found between the control and gabazine groups (Table 3). As above, only EPSPs were observed in the strychnine after gabazine group and the strychnine group. Thus, strychnine completely blocked all IPSPs when given alone or after gabazine injection $\left(\chi^{2}\right.$ test, $p<0.0001$ ), whereas gabazine alone had no significant effect on PSPs $\left(\chi^{2}\right.$ test, $p=0.11$; Fig. $\left.4 G\right)$. Together, as with the segmental interneuronal and PN systems, these data indicate that postsynaptic inhibitory transmission from the bulbospinal system to forelimb motor neurons is mediated by glycine.

\section{Discussion}

The present results demonstrate that, in adult mice, postsynaptic inhibition in spinal forelimb motor neurons evoked from segmental, propriospinal, and bulbospinal systems is mediated by glycine, but not by GABA.

Our results are in agreement with the work that was performed in juvenile animals (Bhumbra et al., 2012) but not in line with data from neonatal animals (Jonas et al., 1998). This discrepancy could partly be attributable to the fact that coexpression of GABA and glycine decreases with age. Indeed, previous studies have shown that glycinergic inhibition increases and becomes functionally dominant, whereas GABAergic inhibition decreases strongly, during the first two postnatal weeks in rat spinal motor neurons (Gao et al., 2001), rat lateral superior olive (Nabekura et al., 2004), and mouse hypoglossal motor neurons (Muller et al., 2006).

Our findings do not exclude the possibility that GABA and glycine are coreleased in the adult spinal cord but, nevertheless, show that there is no clear GABAergic postsynaptic inhibition in adult mouse spinal motor neurons. In addition, much of the previous work in slices from neonatal rats was performed by using the $\mathrm{GABA}_{\mathrm{A}}$ receptor antagonist bicuculline (Jonas et al., 1998; O'Brien and Berger, 1999; Russier et al., 2002), which can also suppress glycine receptors, especially the glycine receptor $\alpha_{2}$ subunit that is predominantly expressed in neonatal rats (Betz et al., 1991; Wang and Slaughter, 2005). Gabazine can also inhibit glycine receptors, but at a higher concentration than what was used to block $\mathrm{GABA}_{\mathrm{A}}$ receptors in motor neurons (Beato, 2008). Here we used gabazine at a concentration that completely blocked GABA-mediated IPSPs in DCN neurons (Fig. 1B), but it had no effect on glycine-evoked IPSPs in spinal motor neurons (Figs. 2-4). Strychnine may also partially block GABA-mediated IPSPs (Jonas et al., 1998). However, such a partial block does not impede the interpretation of our results obtained from motor neurons since we had already blocked $\mathrm{GABA}_{\mathrm{A}}$ receptors with gabazine before administering strychnine. Furthermore, a significant $\mathrm{GABA}_{\mathrm{A}}$ receptor-mediated inhibition is also unlikely because we did not observe any IPSPs after strychnine injection alone.

Our results challenge the current view that both GABA and glycine mediate postsynaptic inhibition in motor neurons in adult animals. Instead, GABA may have a regulatory role on inhibition evoked by glycine; this mechanism has been shown in the 
A

\section{Control}

LRN $100 \mu A \times 2$
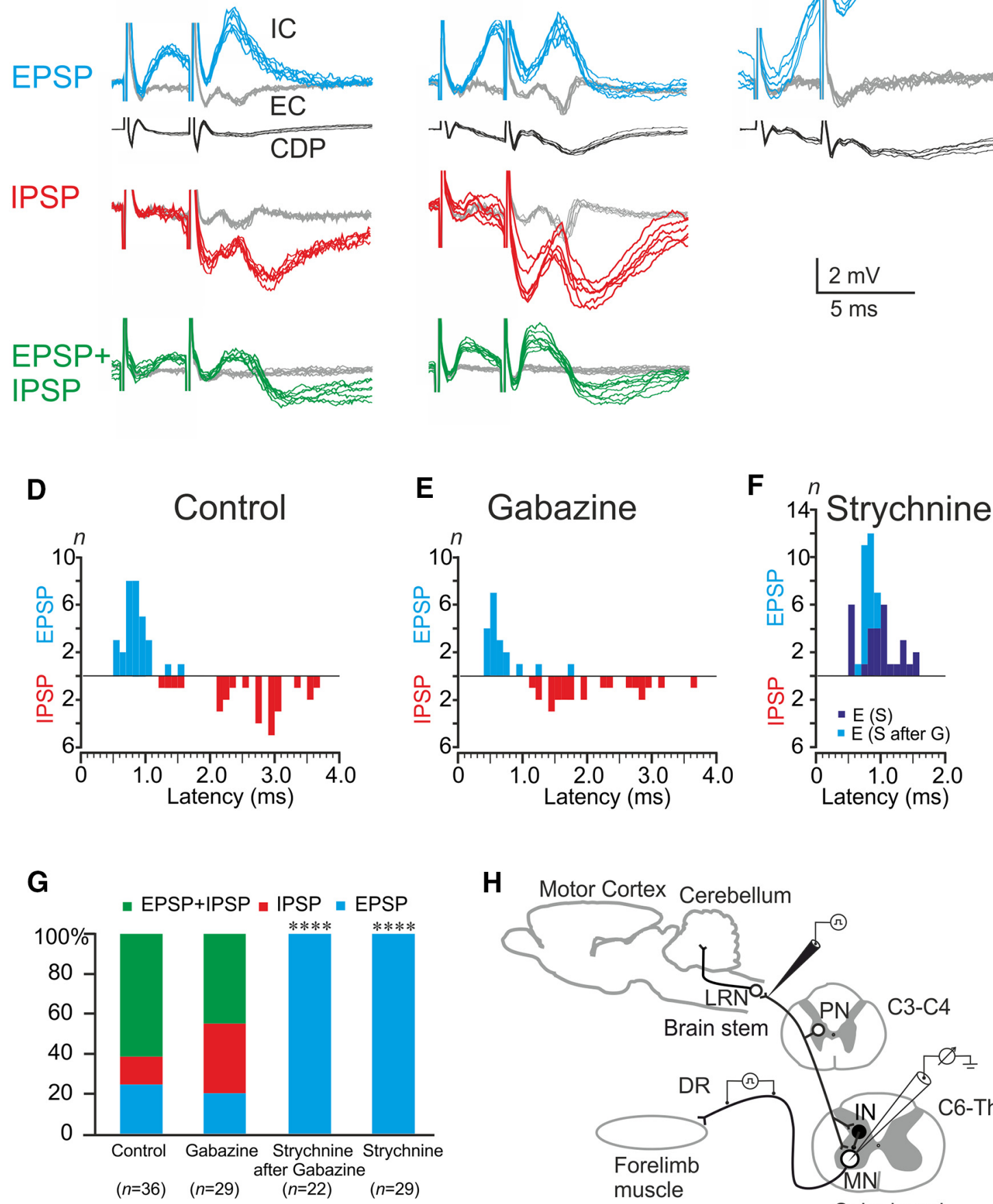

H

Motor Cortex Cerebellum

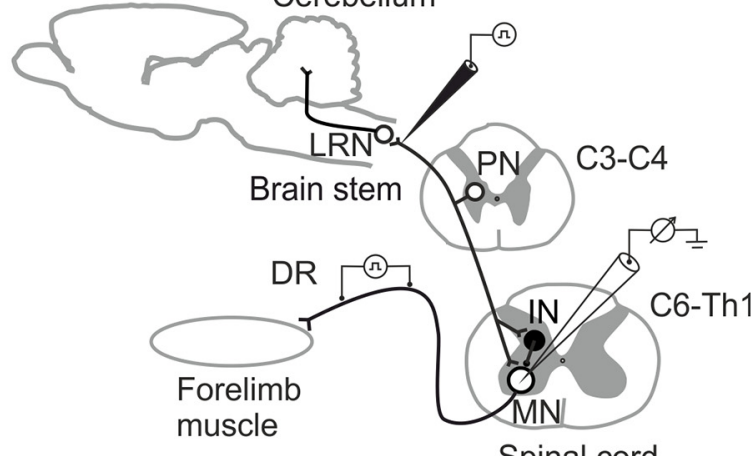

Spinal cord

Figure 3. Effects of gabazine and strychnine on postsynaptic potentials evoked in (6-C7 motor neurons by stimulation in the ipsilateral LRN. A-C, Samples of EPSPs (blue), IPSPs (red), and mixed PSPs (green) in DR motor neurons evoked from ipsilateral LRN in the control $(\boldsymbol{A})$, gabazine $(\boldsymbol{B})$, and strychnine after gabazine $(\boldsymbol{C})$ groups. Black lines show the cord dorsum potential (CDP) recorded at the same segment as the motor neuron. IC, Intracellular recordings; EC, extracellular recordings (gray line). D-F, Segmental latencies of EPSPs and IPSPs in each group. $\mathbf{G}$, Comparison of proportions of EPSPs (blue), IPSPs (red), and EPSP+IPSPs (green) after gabazine or strychnine injection. ${ }^{* * * *} p<0.0001, \chi^{2}$ test, strychnine or strychnine after gabazine injections versus control, respectively. $\boldsymbol{H}$, Experimental design. IN, Interneurons; MN, motor neurons. 
A

\section{Control}

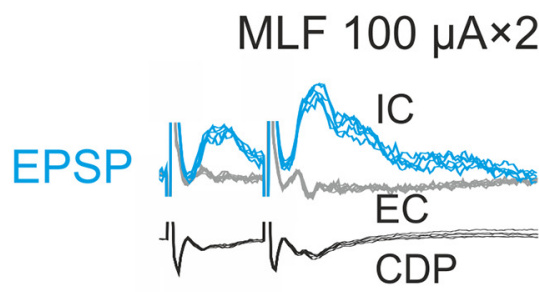

IPSP of

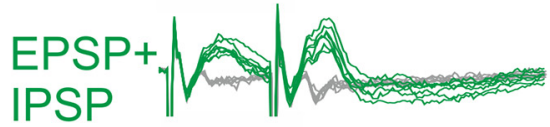

B

Gabazine
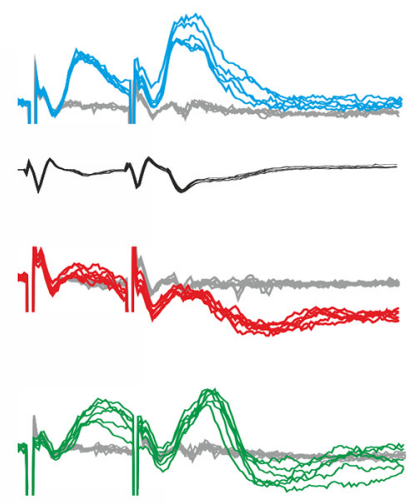

\section{Strychnine}

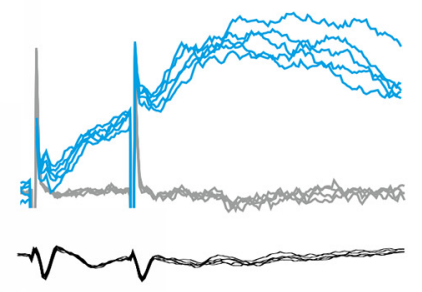

$\frac{2 \mathrm{mV}}{5 \mathrm{~ms}}$
D

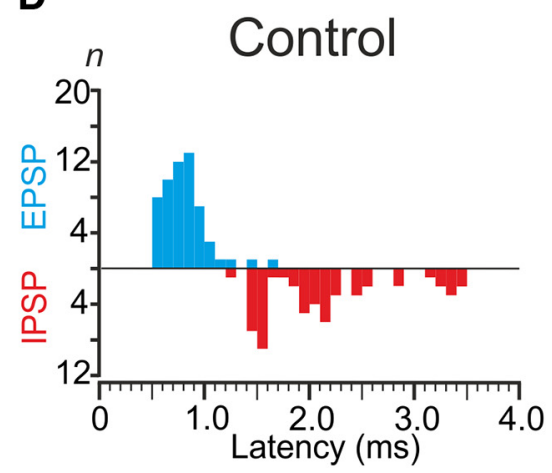

E

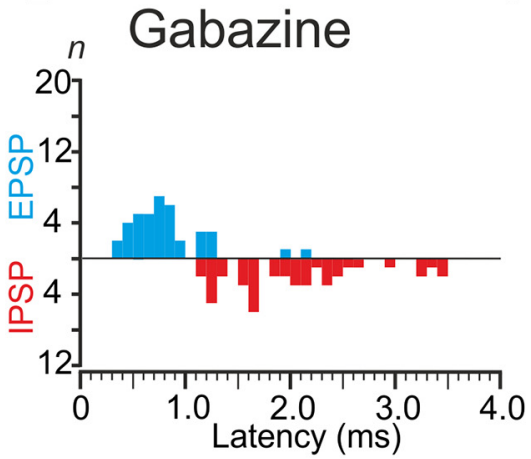

F

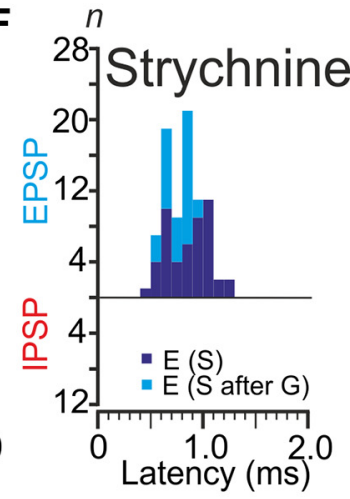

G

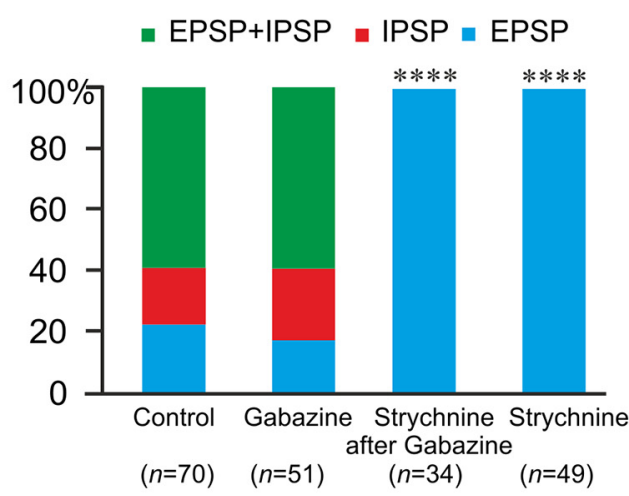

H

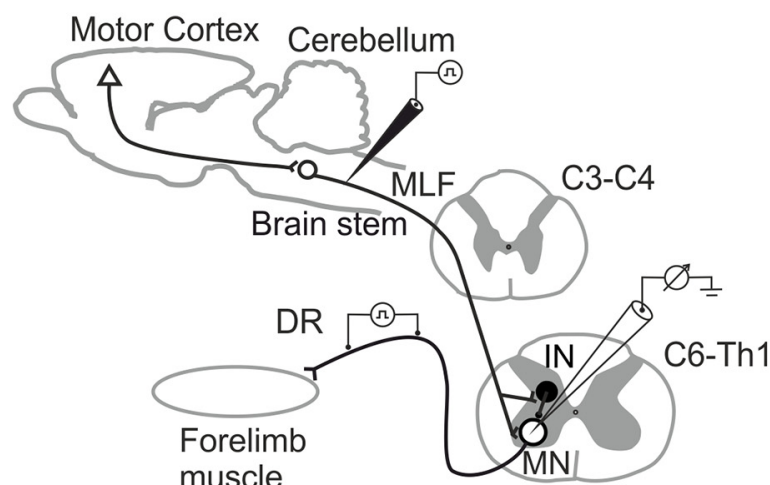

Spinal cord

Figure 4. Effects of gabazine and strychnine on postsynaptic potentials evoked in (6-C7 DR motor neurons by stimulation in the contralateral MLF. A-C, Samples of EPSPS (blue), IPSPs (red), and mixed PSPs (green) in DR motor neurons evoked from MLF in the control $(\boldsymbol{A})$, gabazine $(\boldsymbol{B})$ and strychnine after gabazine $(\boldsymbol{C})$ groups. Black lines show the cord dorsum potential (CDP) recorded at the same segment as the motor neuron. IC, Intracellular recordings; EC, extracellular recordings (gray line). D-F, Segmental latencies of EPSPs and IPSPs in each group. G, Comparison of proportions of EPSPs (blue), IPSPs (red), and EPSP+IPSPs (green) after gabazine or strychnine injection. ${ }^{* * *} p<0.0001, \chi^{2}$ test, strychnine or strychnine after gabazine injections versus control, respectively. $\boldsymbol{H}$, Experimental design. IN, Interneurons; MN, motor neurons.

auditory system (Lu et al., 2008) where GABA can significantly shorten the decay time of glycine-evoked IPSCs and play a role in increasing the temporal resolution of inhibition. We note that our results do not exclude the possibility that $\mathrm{GABA}_{\mathrm{A}}$ receptors are involved in controlling motor neuron excitability. $\mathrm{GABA}_{\mathrm{A}}$ receptor-mediated presynaptic inhibition is well documented in the spinal cord where GABA plays an important role in modulating the strength of sensory-motor transmission (Rudomin and 
Schmidt, 1999; Betley et al., 2009; Fink et al., 2014). Moreover, GABA may also exert an effect through extrasynaptic GABA $_{\mathrm{A}}$ receptors to modulate glutamate or glycine responses (Bautista et al., 2010).

Interestingly, in a transgenic mouse model of amyotrophic lateral sclerosis, glycinergic inhibition is reduced whereas $\mathrm{GABA}_{\mathrm{A}}$ receptor function appears normal (Martin and Chang, 2012). This adult-onset neurodegenerative disease is characterized by progressive loss of motor neurons and hyperexcitability. Our findings could help explain why hyperexcitability in the diseased motor neurons cannot be compensated for by GABA-evoked postsynaptic inhibition.

In conclusion, our findings suggest a prominent role for glycinergic inhibitory transmission in normal motor control in adult mice. Moreover, these results agree well with the classical work by Eccles (1964) and colleagues in the cat, implicating glycinergic signaling as an evolutionarily conserved and exclusive mechanism for postsynaptic motor neuron inhibition.

\section{References}

Alstermark B, Ogawa J (2004) In vivo recordings of bulbospinal excitation in adult mouse forelimb motoneurons. J Neurophysiol 92:1958-1962. CrossRef Medline

Alstermark B, Lundberg A, Sasaki S (1984) Integration in descending motor pathways controlling the forelimb in the cat. 10. Inhibitory pathways to forelimb motoneurones via C3-C4 propriospinal neurones. Exp Brain Res 56:279-292. CrossRef Medline

Azim E, Jiang J, Alstermark B, Jessell TM (2014) Skilled reaching relies on a V2a propriospinal internal copy circuit. Nature 508:357-363. CrossRef Medline

Baldissera F, Hulborn H, Illert M (1981) Integation in spinal neuronal systems. In: Handbook of Physiology-The nervous system II (Brooks VB, ed.), Chap 12, pp 509-595. Bethesda, MD: American Physiological Society.

Bautista W, Aguilar J, Loeza-Alcocer JE, Delgado-Lezama R (2010) Pre- and postsynaptic modulation of monosynaptic reflex by GABAA receptors on turtle spinal cord. J Physiol 588:2621-2631. CrossRef Medline

Beato M (2008) The time course of transmitter at glycinergic synapses onto motoneurons. J Neurosci 28:7412-7425. CrossRef Medline

Betley JN, Wright CV, Kawaguchi Y, Erdélyi F, Szabó G, Jessell TM, Kaltschmidt JA (2009) Stringent specificity in the construction of a GABAergic presynaptic inhibitory circuit. Cell 139:161-174. CrossRef Medline

Betz H, Langosch D, Hoch W, Prior P, Pribilla I, Kuhse J, Schmieden V, Malosio ML, Matzenbach B, Holzinger F, Kuryatov A, Schmitt B, Maulet Y, Becker CM (1991) Structure and expression of inhibitory glycine receptors. Adv Exp Med Biol 287:421-429. CrossRef Medline

Bhumbra GS, Moore NJ, Moroni M, Beato M (2012) Co-release of GABA does not occur at glycinergic synapses onto lumbar motoneurons in juvenile mice. Front Cell Neurosci 6:1-11. CrossRef Medline

Coombs JS, Eccles JC, Fatt P (1955) The inhibitory suppression of reflex discharges from motoneurones. J Physiol 130:396-413. Medline

Curtis DR, Felix D (1971) GABA and prolonged spinal inhibition. Nat New Biol 231:187-188. CrossRef Medline

Curtis DR, Hösli L, Johnston GA (1967) Inhibition of spinal neurons by glycine. Nature 215:1502-1503. CrossRef Medline

Curtis DR, Hösli L, Johnston GA, Johnston IH (1968) The hyperpolarization of spinal motoneurones by glycine and related amino acids. Exp Brain Res 5:235-258. Medline
Eccles JC (1964) The physiology of synapses. Berlin: Springer.

Fink AJ, Croce KR, Huang ZJ, Abbott LF, Jessell TM, Azim E (2014) Presynaptic inhibition of spinal sensory feedback ensures smooth movement. Nature 509:43-48. CrossRef Medline

Frazao R, Nogueira MI, Wässle H (2007) Colocalization of synaptic $\mathrm{GABA}(\mathrm{C})$-receptors with $\mathrm{GABA}(\mathrm{A})$-receptors and glycine-receptors in the rodent central nervous system. Cell Tissue Res 330:1-15. CrossRef Medline

Gao BX, Stricker C, Ziskind-Conhaim L (2001) Transition from GABAergic to glycinergic synaptic transmission in newly formed spinal networks. J Neurophysiol 86:492-502. Medline

Holstege JC, Calkoen F (1990) The distribution of GABA in lumbar motoneuronal cell groups. A quantitative ultrastructural study in rat. Brain Res 530:130-137. CrossRef Medline

Illert M, Tanaka R (1978) Integration in descending motor pathways controlling the forelimb in the cat. 4. Corticospinal inhibition of forelimb motoneurones mediated by short propriospinal neurones. Exp Brain Res 31:131-141. Medline

Isa T, Ohki Y, Seki K, Alstermark B (2006) Properties of propriospinal neurons in the $\mathrm{C} 3-\mathrm{C} 4$ segments mediating disynaptic pyramidal excitation to forelimb motoneurons in the macaque monkey. J Neurophysiol 95:36743685. CrossRef Medline

Ito M, Yoshida M, Obata K, Kawai N, Udo M (1970) Inhibitory control of intracerebellar nuclei by the Purkinje cell axons. Exp Brain Res 10:64-80. CrossRef Medline

Jonas P, Bischofberger J, Sandkühler J (1998) Corelease of two fast neurotransmitters at a central synapse. Science 281:419-424. CrossRef Medline

Lu T, Rubio ME, Trussell LO (2008) Glycinergic transmission shaped by the corelease of GABA in a mammalian auditory synapse. Neuron 57:524535. CrossRef Medline

Martin LJ, Chang Q (2012) Inhibitory synaptic regulation of motoneurons: a new target of disease mechanisms in amyotrophic lateral sclerosis. Mol Neurobiol 45:30-42. CrossRef Medline

Muller E, Le Corronc H, Triller A, Legendre P (2006) Developmental dissociation of presynaptic inhibitory neurotransmitter and postsynaptic receptor clustering in the hypoglossal nucleus. Mol Cell Neurosci 32:254273. CrossRef Medline

Nabekura J, Katsurabayashi S, Kakazu Y, Shibata S, Matsubara A, Jinno S, Mizoguchi Y, Sasaki A, Ishibashi H (2004) Developmental switch from GABA to glycine release in single central synaptic terminals. Nat Neurosci 7:17-23. CrossRef Medline

O’Brien JA, Berger AJ (1999) Cotransmission of GABA and glycine to brain stem motoneurons. J Neurophysiol 82:1638-1641. Medline

Ornung G, Shupliakov O, Lindå H, Ottersen OP, Storm-Mathisen J, Ulfhake B, Cullheim S (1996) Qualitative and quantitative analysis of glycineand GABA-immunoreactive nerve terminals on motoneuron cell bodies in the cat spinal cord: a postembedding electron microscopic study. J Comp Neurol 365:413-426. Medline

Rudomin P, Schmidt RF (1999) Presynaptic inhibition in the vertebrate spinal cord revisited. Exp Brain Res 129:1-37. CrossRef Medline

Russier M, Kopysova IL, Ankri N, Ferrand N, Debanne D (2002) GABA and glycine co-release optimizes functional inhibition in rat brainstem motoneurons in vitro. J Physiol 541:123-137. CrossRef Medline

Todd AJ, Watt C, Spike RC, Sieghart W (1996) Colocalization of GABA, glycine, and their receptors at synapses in the rat spinal cord. J Neurosci 16:974-982. Medline

Wang P, Slaughter MM (2005) Effects of GABA receptor antagonists on retinal glycine receptors and on homomeric glycine receptor alpha subunits. J Neurophysiol 93:3120-3126. CrossRef Medline 